\title{
The convective storm system during IOP 2a of MAP: Cloud-to-ground lightning flash production in relation to dynamics and microphysics
}

\author{
By Y. SEITY ${ }^{1 *}$, S. SOULA ${ }^{1}$, P. TABARY ${ }^{2}$ and G. SCIALOM ${ }^{2}$ \\ ${ }^{1}$ Laboratoire d'Aérologie, CNRS and Université Paul Sabatier, Toulouse, France \\ ${ }^{2}$ Centre d'étude des Environnements Terrestre et Planétaires, CNRS, Vélizy, France
}

\begin{abstract}
SUMMARY
This paper presents a study about correlation between cloud-to-ground lightning flash (CG) activity, and the dynamics and microphysics of thunderclouds. Data collected during Intense Observation Period (MAP IOP) 2a of the Mesoscale Alpine Programme Special Observing Period (SOP) over the Lago Maggiore Target Area (LMTA) in northern Italy are used. IOP 2a was the most electrically active period during the SOP, representing $75 \%$ of the total CG activity. Thunderclouds were strongly vertically developed (the $30 \mathrm{dBZ}$ echo tops were sometimes higher than $12 \mathrm{~km}$ ) and produced large amounts of rainfall and some hail. Doppler and polarimetric radar data allow us to retrieve the three-dimensional wind and radar-reflectivity fields from two synchronous Doppler radars, and particle-type fields in the thunderclouds from the S-Pol polarimetric radar. Both polarities of CGs are distinguished. Temporal and spatial relationships from the global activity over the LMTA are first studied. Then, the temporal correlation between CG rates and dynamics or microphysics for five individual cells is considered. A very strong correlation is observed between CG and the presence of a mixture of graupel and hail, which strongly supports a non-inductive charging mechanism. CG impacts seem to be located underneath large radar-reflectivity values and around the maximum vertical velocities. Two individual cells are studied in more detail, in order to better understand their different electrical behaviours: the first produced mainly negative CGs, and the second produced $61 \%$ positive CGs in the second phase of its lifetime. The association of positive CGs with severe weather and especially with the presence of hail is observed.
\end{abstract}

KeYWords: Mesoscale Alpine Programme Storm microphysics and dynamics

\section{INTRODUCTION}

Thunderstorm lightning flash activity has been considered in many studies, from observations by local electrostatic field-change measurements (Jacobson and Krider 1976), by ground networks (Orville 1994; Zajac and Rutledge 2001; Seity et al. 2001) or by satellite (Christian et al. 1999; Petersen and Rutledge 2001). Some of these facilities allow separation of different types of flash: positive/negative, cloud-to-ground and intra-cloud flashes. In the following sections, IC, CG, $+\mathrm{CG}$, and $-\mathrm{CG}$ refer to intra-cloud flash, cloud-to-ground flash, positive cloud-to-ground flash, and negative cloud-to-ground flash, respectively.

Concerning the CGs, most of them lower negative charge to ground ( $-\mathrm{CGs})$. For example, annual flash statistics compiled for the contiguous USA over a 5-year period by Zajac and Rutledge (2001) indicated that less than $10 \%$ of CGs were +CGs. In the warm season +CGs can occur during the dissipating stage or in association with the anvils of large storms (Rust et al. 1981a,b) or in mesoscale convective systems (MCSs, Rutledge et al. 1990). However, some observations show large proportions of +CGs during the life of isolated storms. They can correspond to shallow cells as indicated by Engholm et al. (1990), or to severe thunderstorms as observed by Branick and Doswell (1992), Seimon (1993), MacGorman and Burgess (1994), Stolzenburg (1994) and Carey and Rutledge (1998). Several questions motivated this study. (i) The processes responsible for storm electrification are not currently well known, most theories are based on microphysics and particle interaction in the presence or absence of an ambient electric field; the present study tries to identify what microphysics is present in storms

${ }^{*}$ Corresponding author, present address: UMR 5560 UPS/CNRS, 14 av. E. Belin, 31400 Toulouse, France. e-mail: seiy@ aero.obs-mip.fr 
producing CGs. (ii) A further question concerns the dynamical and microphysical differences between thunderclouds producing mainly -CGs and those producing +CGs. (iii) Many questions remain concerning the understanding of thunderclouds producing severe weather (hail, tornadoes, heavy precipitation) associated with +CGs. It will be very useful to better describe these thunderstorms which, although quite rare, cause considerable damage because of strong winds and flash floods, especially over hilly areas such as south-eastern France and northern Italy.

In the autumn of 1999, a comprehensive dataset on CG activity, together with the dynamics and microphysics of orographic thunderstorms, was collected during the Mesoscale Alpine Programme (MAP) Special Observing Period (SOP, Bougeault et al. 2001). This dataset is perfectly suited to the study of the above questions. Our study is part of the P1 objective of MAP (Bougeault et al. 2001) concerning orographic precipitation mechanisms. This is approached through the study of electrical activity produced by thunderclouds over the relief.

According to climatic studies, the Lago Maggiore Target Area (LMTA) displays among the highest cumulative rainfall (Frei and Schär 1998) and CG densities (Iorio and Ferrari 1997) over the Alps. The Intensive Observing Period (IOP) 2a of the SOP, on 17 and 18 September 1999, was characterized by a strong rainfall event with isolated cells; however, other cells organized along a squall line with strong vertical development (radar $30 \mathrm{dBZ}$ echo tops were observed at a height of $12 \mathrm{~km}^{*}$ ). LMTA was covered by three Doppler radars and hence this case constitutes an opportunity to study the relationships between CG activity and the other physical characteristics of the thundercloud. This study covers two aspects, a statistical one taking into account the whole area and the whole lifetime of a convective system, and another aspect considering individual cells with specific characteristics and evolution. Section 2 presents the dataset the present study relies upon, and section 3 gives a brief overview of IOP 2a. In section 4, average statistical relationships between CGs, and the dynamics and microphysics observed during IOP $2 \mathrm{a}$ are described. Five individual cells are then studied and a temporal correlation between their activities discussed in section 5. A detailed comparison between two cells with different characteristics and evolution in terms of $-\mathrm{CG}$ and $+\mathrm{CG}$ production is given in section 6. Section 7 is a discussion of the observations presented in the previous sections, and conclusions are drawn in section 8 .

\section{DATA}

The location of the three Doppler radars of LMTA used for this study is shown in Fig. 1. They covered the LMTA with a common observed area of about $140 \times 140 \mathrm{~km}^{2}$ and comprised: the French C-band Doppler RONSARD radar of the Centre d'Étude des Environnements Terrestre et Planétaires (CETP); the operational C-band Doppler Monte-Lema radar of the Swiss Meteorological Agency (SMA); and the American Sband Doppler/Polarimetric S-Pol radar of the National Center for Atmospheric Research (NCAR). They are, from now on, called RONSARD, Monte-Lema and S-Pol, respectively. Figure 1 also shows the Milano Linate radiosonde station. The RONSARD sampling strategy was synchronized with the Monte-Lema routine operations so as to allow real-time dual-Doppler wind synthesis during the SOP (Chong et al. 2000). External circles in Fig. 1 indicate the dual-Doppler area of Monte-Lema and RONSARD. The nominal synchronization time was set to 15 minutes. For example, the 1715 UTC radar picture is representative of the situation between 1715 and 1730 UTC. The multipleDoppler analysis method (MANDOP) used to retrieve the three-dimensional wind and

* Heights are given above mean sea level unless otherwise stated. 


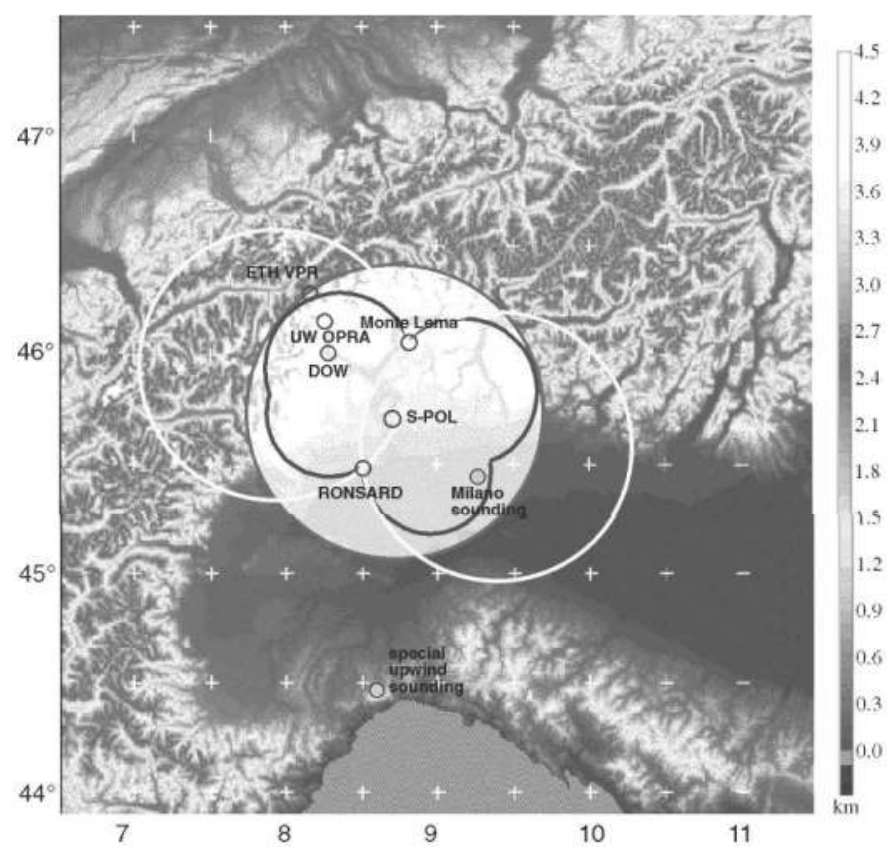

Figure 1. Map of the experimental study zone in northern Italy. The Lago Maggiore Target Area is covered by circles representing the dual-doppler RONSARD/Monte-Lema area and that of S-Pol. The relief is described with a grey scale from 0 to $4.5 \mathrm{~km}$.

reflectivity fields from Doppler radar measurements has been described and thoroughly tested with synthetic and real data by Tabary and Scialom (2001). Because MANDOP is based on a representation of the components in terms of orthonormal polynomials over the domain of interest, an implicit filtering is performed in which the cut-off wavelength is dependent on the order $n$ of the expansion as $2 L /(n-1)$, where $L$ is the size of the domain. In this study $L=100 \mathrm{~km}$ and $n=8$, yielding a cut-off length of $28.6 \mathrm{~km}$. This indicates that the minimum observable scale, i.e. the characteristic-scale of variations, is about $7.5 \mathrm{~km}$. Hence, with this method convective-scale features of a few kilometres are smoothed. In particular, convective updraught magnitudes appear reduced by about $30 \%$. S-Pol performed Range Height Indicator (RHI) and Plan Position Indicator (PPI) scans according to the area of interest. The microphysical structure of the convective system during its successive stages of development has been retrieved using the particletype identification algorithm described in Vivekanandan et al. (1999). The input data of the algorithm are the polarimetric measurements (reflectivity factor $Z$, differential reflectivity $Z D R$, correlation coefficient at zero time lag $\left|\rho_{\mathrm{HV}}\right|$, specific differential phase $K D P$, and linear depolarisation ratio $L D R$ ) and the temperature profile. From this set of parameters, the dominant particle type is retrieved using a fuzzy-logic algorithm. The particles are separated into 11 types: light rain (LR), moderate rain (MR), heavy rain (HR), large drops (LD), hail (HL), rain/hail mixture (RH), graupel/hail mixture (GH), dry snow (DS), wet snow (WS), horizontally aligned crystals (HC) and vertically aligned crystals (VC). The result is thus a tendency in terms of probability of the dominant particle type, and the particle type indicated is the most probable.

The radar dataset used in this study consists of 15-minute analyses between 1400 and 1900 UTC (when cells developed over the relief), and 30-minute analyses between 1930 and 0200 UTC (when cells are over the plain in a squall-line structure). Data are 


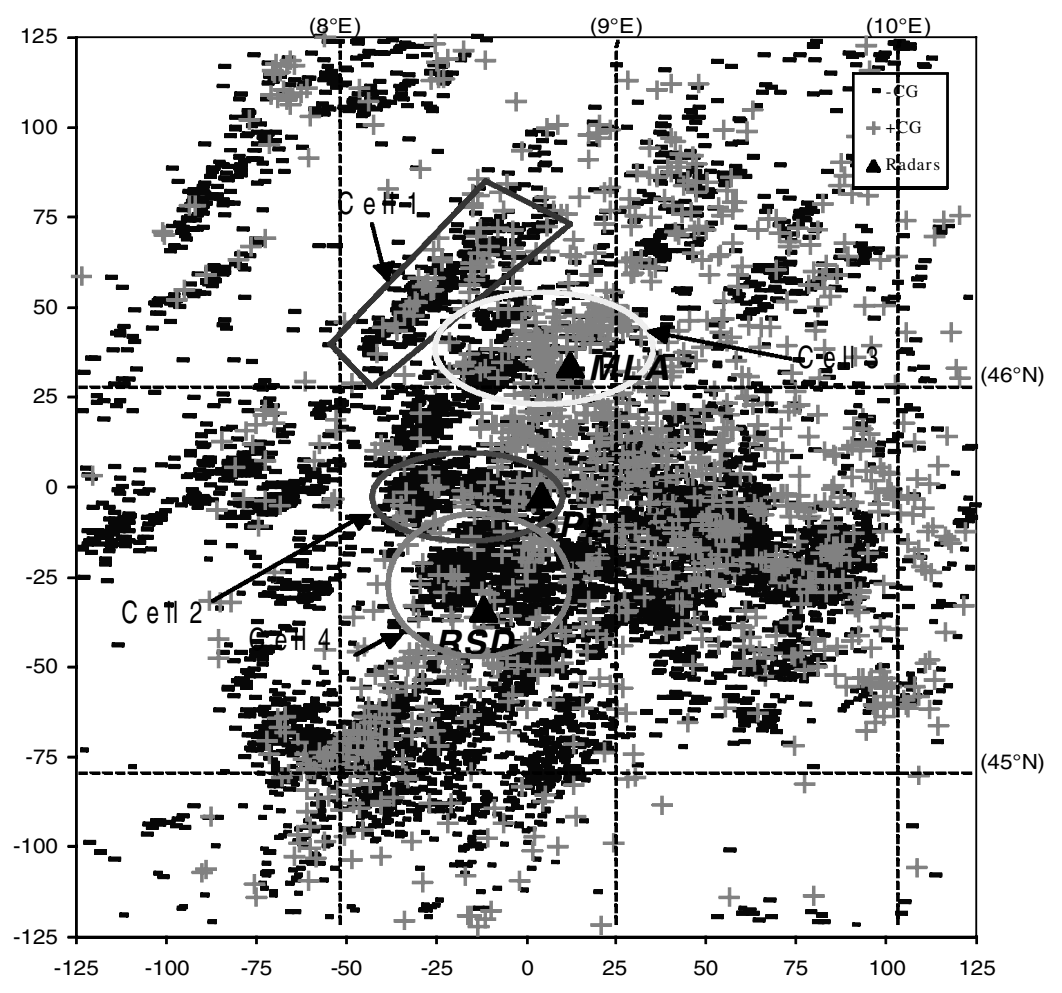

Figure 2. Cloud-to-ground lightning strokes (CGs) over a $250 \times 250 \mathrm{~km}^{2}$ area centred on the middle of the Monte-Lema/RONSARD axis. It represents a total of 9975 CG impacts, with $1360+$ CGs. Locations of the three radars, RONSARD, Monte-Lema and S-Pol, are at RSD, MLA and SP, respectively. See text for further details.

missing at 1530 and 1545 UTC. Polarimetric data were processed with the same temporal resolution until 2300 UTC and are missing at 1530, 1545, 1700, and 1730 UTC.

During the SOP, data from six national lightning-detection networks (29 stations) were combined by the ALDIS company. These networks detected CGs with an efficiency of more than 90\% over LMTA (Schulz 1997). Each station is equipped with a crossed loop antenna which detects the magnetic field radiated by the return stroke of the CG. A shape-recognition procedure identifies the signal generated by the return stroke, whose channel is roughly vertical near the ground. This detection is made at low frequency $(1-300 \mathrm{kHz})$ because the return stroke is the most energetic phase in terms of electromagnetic field at this frequency range. Each station provides the direction of the ground strike generating the electromagnetic wave. When the same signal is detected by several stations, the location of this impact can be estimated by triangular calculation. In addition to the time and location of each $\mathrm{CG}$, the system provides the polarity and peak-current of the first return stroke, as well as the multiplicity of the flash. Special care is required concerning low peak-current + CGs which may be false detections of ICs (Pinto et al. 1999; Théry 2001).

\section{OVERVIEW OF IOP $2 \mathrm{~A}$}

IOP $2 \mathrm{a}$ is the most useful MAP IOP for studying the various scientific questions indicated in section 1 . It was the most electrically active IOP during the SOP: over an area of $250 \times 250 \mathrm{~km}^{2}$ centred near S-Pol, 9880 CGs were detected between 1400 UTC 
17 September and 0200 UTC 18 September (Fig. 2). This represents a mean rate of 14 CGs per minute for $12 \mathrm{~h}$, and about $75 \%$ of the flashes detected during the whole SOP.

The intense convective activity was due to an eastward moving trough. At low levels, LMTA was supplied by warm and moist air from two converging flows-from the Adriatic sea (easterly flow) and the Mediterranean sea (southerly flow). The lowlevel flow probably arose from a mesoscale blocking phenomenon against the Alps (Pierrehumbert and Wyman 1985). This phenomenon is rather common in that region under southerly or south-westerly regimes. Indeed, at $500 \mathrm{hPa}$ the flow was mainly south-westerly and moderate $\left(20 \mathrm{~m} \mathrm{~s}^{-1}\right)$.

From 1400 UTC, the first convective cells appeared over the south-eastward facing slopes of the mountains (Tabary 2002). They moved north-eastwards parallel to the midand upper-level flow. Some of them, with strong vertical development, produced many CGs and intense rainfall. Cumulative rainfall higher than $70 \mathrm{~mm}$ over $6 \mathrm{~h}$ was locally recorded. Hail was also observed within some thunderclouds. On 17 September, the 1800 UTC Milano Linate radiosounding indicated atmospheric instability, with values of convective available potential energy (CAPE) and convective inhibition estimated at about 1000 and $-55 \mathrm{~J} \mathrm{~kg}^{-1}$, respectively. After $1900 \mathrm{UTC}$, the thunderclouds were mainly located over the plain. Most of them were embedded in a south-west to north-east oriented squall line which evolved until 0200 UTC on 18 September. The cells studied over LMTA were part of a 400 (north-south) $\times 100$ (west-east) $\mathrm{km}^{2}$ MCS. The initial large-scale conditions for IOP $2 \mathrm{a}$, the dynamical and microphysical structure and the evolution of this system are described with more details in Tabary (2002).

\section{RELATION BETWEEN CG AND DYNAMICAL/MICROPHYSICAL CHARACTERISTICS}

An example of the relationship between $\mathrm{CG}$ and dynamical and microphysical characteristics is given in Fig. 3. It shows horizontal cross-sections for 1715 and 1830 UTC at altitude $7 \mathrm{~km}$ with the impact locations of CGs superimposed. CGs seem to be closely associated with high radar-reflectivity values and $\mathrm{GH}$ particles, and less closely with strong vertical velocities.

To quantify these relations, and better understand the overall relationships between the dynamical, microphysical, and electrical characteristics of the thunderclouds, radar characteristics are examined as a function of altitude and CG polarity. Radar data were available over a $100 \times 100 \times 12 \mathrm{~km}^{3}$ volume, with a spatial resolution of $2.5 \times 2.5 \times$ $0.3 \mathrm{~km}^{3}$. This represents $41 \times 41 \times 41$ grid points. Two methods are considered.

- In Method 1, the goal is to look for the environmental conditions of each CG. For each a vertical cylinder centred on the ground impact is chosen. $r$ is the radius of this cylinder between the ground and height $z=12 \mathrm{~km}$. Within the multipledoppler coverage area 3080 -CGs and 427 +CGs are considered. For each CG, several parameters are extracted from the associated cylinder: (i) the maximum vertical velocity, $w_{\max }$; (ii) the maximum radar reflectivity, $Z_{\max }$; and (iii) the distribution of the 11 particle types over the cylinder.

- Method 2 is the reverse of Method 1. For each radar picture and for each grid point $(41 \times 41 \times 41$ points $)$, the test focused on whether at least one CG strike in the base of the cylinder of radius $r$, centred on the considered grid point, could be found at the ground. The $+\mathrm{CG}$ and the $-\mathrm{CG}$ sere also discriminated.

Both methods are complementary: the first describes the dynamical and microphysical conditions associated with each lightning flash, and the second evaluates the probability of lightning flash occurrence for given dynamical and microphysical conditions. 

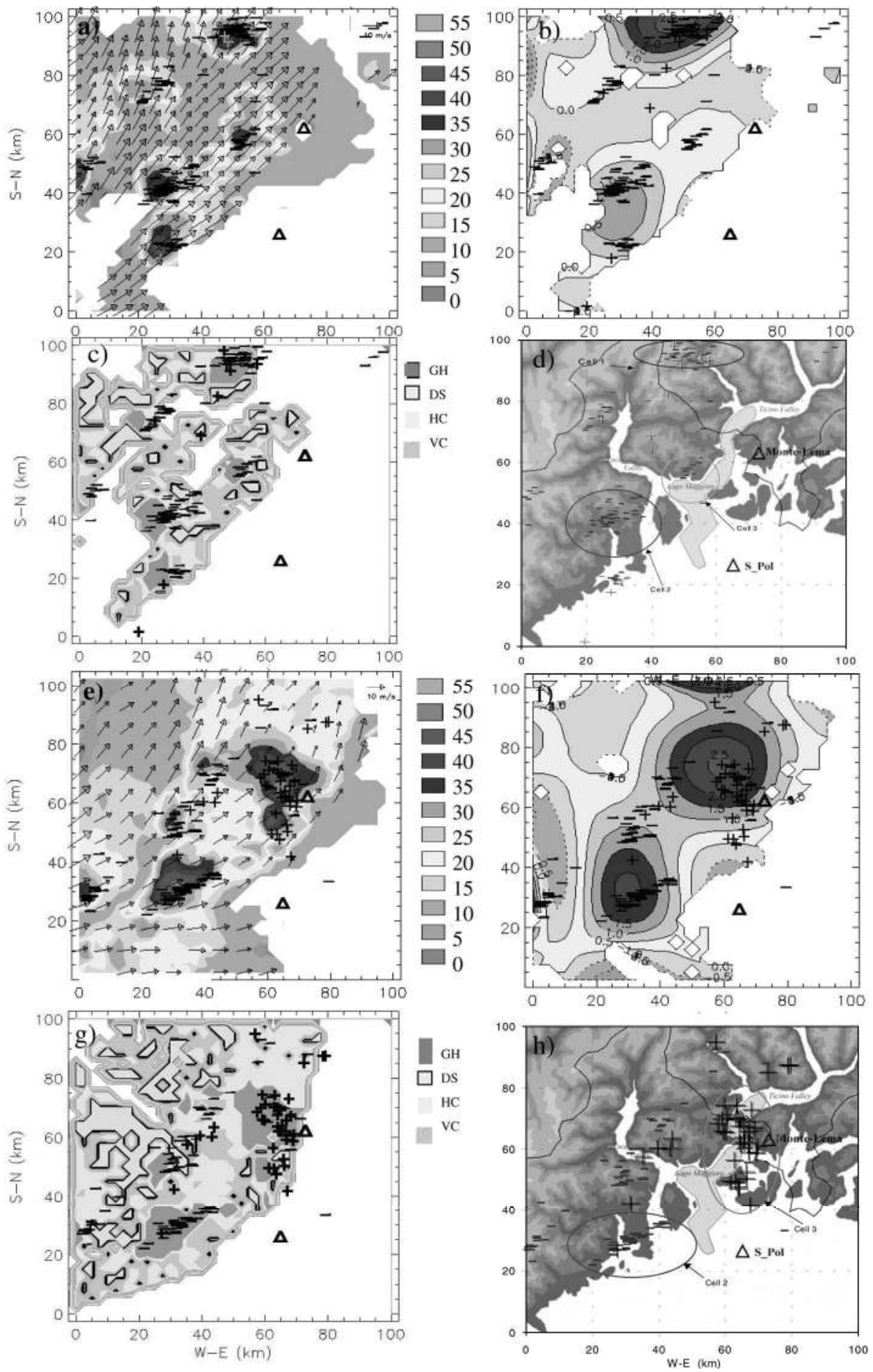

Figure 3. Cross-sections at $7 \mathrm{~km}$ above mean sea level over the Lago Maggiore Target Area on 17 September 1999 of: (a) 1715 UTC horizontal radar reflectivity in $\mathrm{dBZ}$, (b) $1715 \mathrm{UTC}^{\mathrm{U}}$ vertical velocity in $\mathrm{m} \mathrm{s}^{-1}$, (c) $1715 \mathrm{UTC}^{-1}$ particle type, (d) 1715 UTC relief and locations of cloud-to-ground lightning impacts (CGs); (e) to (h) are as (a) to (d), respectively, but for 1830 UTC. The $100 \times 100 \mathrm{~km}^{2}$ study area is centred at $45.65^{\circ} \mathrm{N}, 8.74^{\circ} \mathrm{W}$. Positive CGs $(+)$ and negative CGs $(-)$ occurring in the 15-minute interval associated with each radar picture are superimposed. See text for details of particle types. 

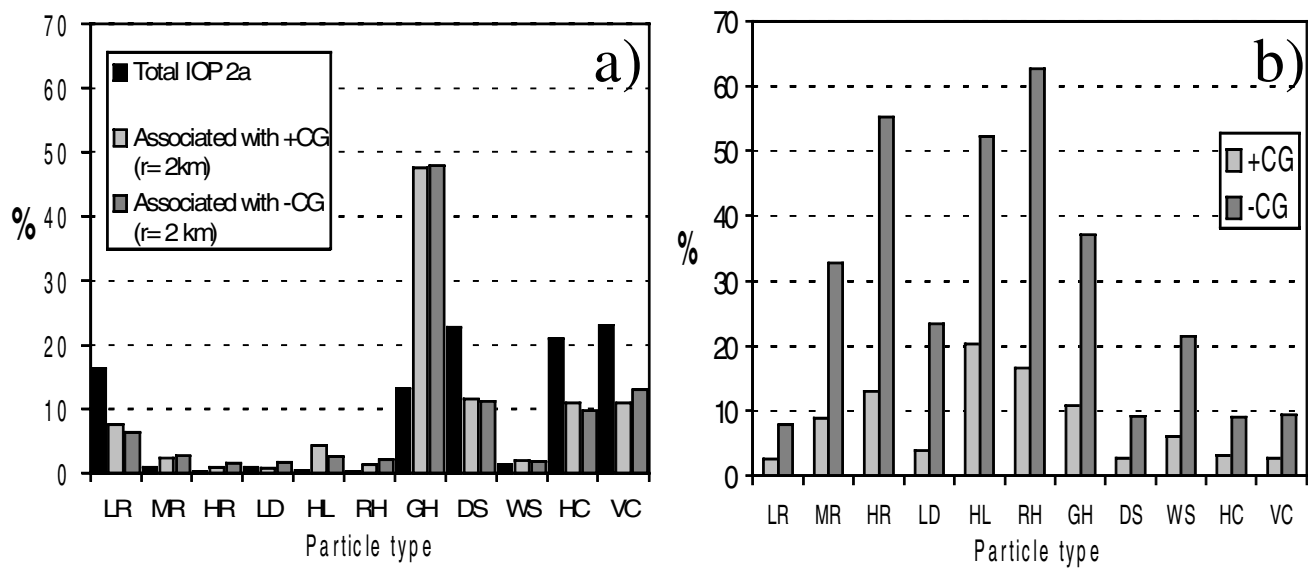

Figure 4. Relationships between cloud-to-ground lightning strikes (CGs) and particle types in IOP 2a: (a) CG percentages versus particle type according to Method 1 (see text) within a cylinder of radius $r=2 \mathrm{~km}$; (b) particletype percentages versus positive and negative CGs according to Method 2 with $r=2 \mathrm{~km}$. The 11 particle types are: light rain $\mathrm{LR}$, moderate rain $\mathrm{MR}$, heavy rain $\mathrm{HR}$, large drops $\mathrm{LD}$, hail $\mathrm{HL}$, rain/hail mixture $\mathrm{RH}$, graupel/hail mixture GH, dry snow DS, wet snow WS, horizontally aligned crystals HC and vertically aligned crystals VC.

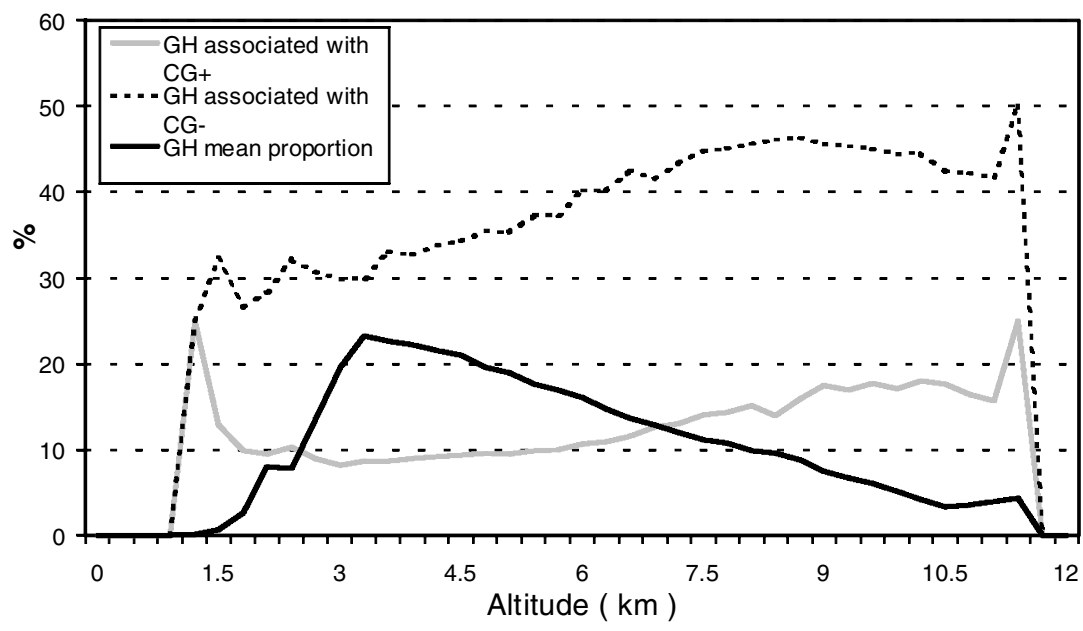

Figure 5. In IOP 2a within a cylinder of radius $2 \mathrm{~km}$ using Method 2: proportions of graupel/hail particles (GH) associated with positive and negative cloud-to-ground lightning strikes (CGs) versus altitude, and proportion of $\mathrm{GH}$ amongst the 11 particle types. See text for details.

\section{(a) Correspondence with particle type}

According to Fig. 4(a), which corresponds to Method 1 with $r=2 \mathrm{~km}$, there is no significant difference between the particle distributions associated with -CGs and + CGs. The most significant observation is that GH fills about $47 \%$ of the cylindrical volumes, whereas this particle type represents no more than $13 \%$ of the particles observed during the whole of IOP 2a. Other calculations with $r=2 \mathrm{~km}$ have shown that $\mathrm{GH}$ is the dominant particle type, representing more than $50 \%$ of the cylinder's volume in $79 \%$ of - CGs and $73 \%$ of + CGs.

Conversely, in Method 2 with $r=2 \mathrm{~km} \mathrm{Fig.} \mathrm{4(b)} \mathrm{shows} \mathrm{that} \mathrm{the} \mathrm{particle} \mathrm{type} \mathrm{that} \mathrm{is}$ better associated with $-\mathrm{CGs}$ is $\mathrm{RH}(62 \%)$, and $\mathrm{HL}$ is the type that is better associated with + CGs (20\%). GH is only associated with -CGs in $38 \%$ and +CGs in $11 \%$ of the 

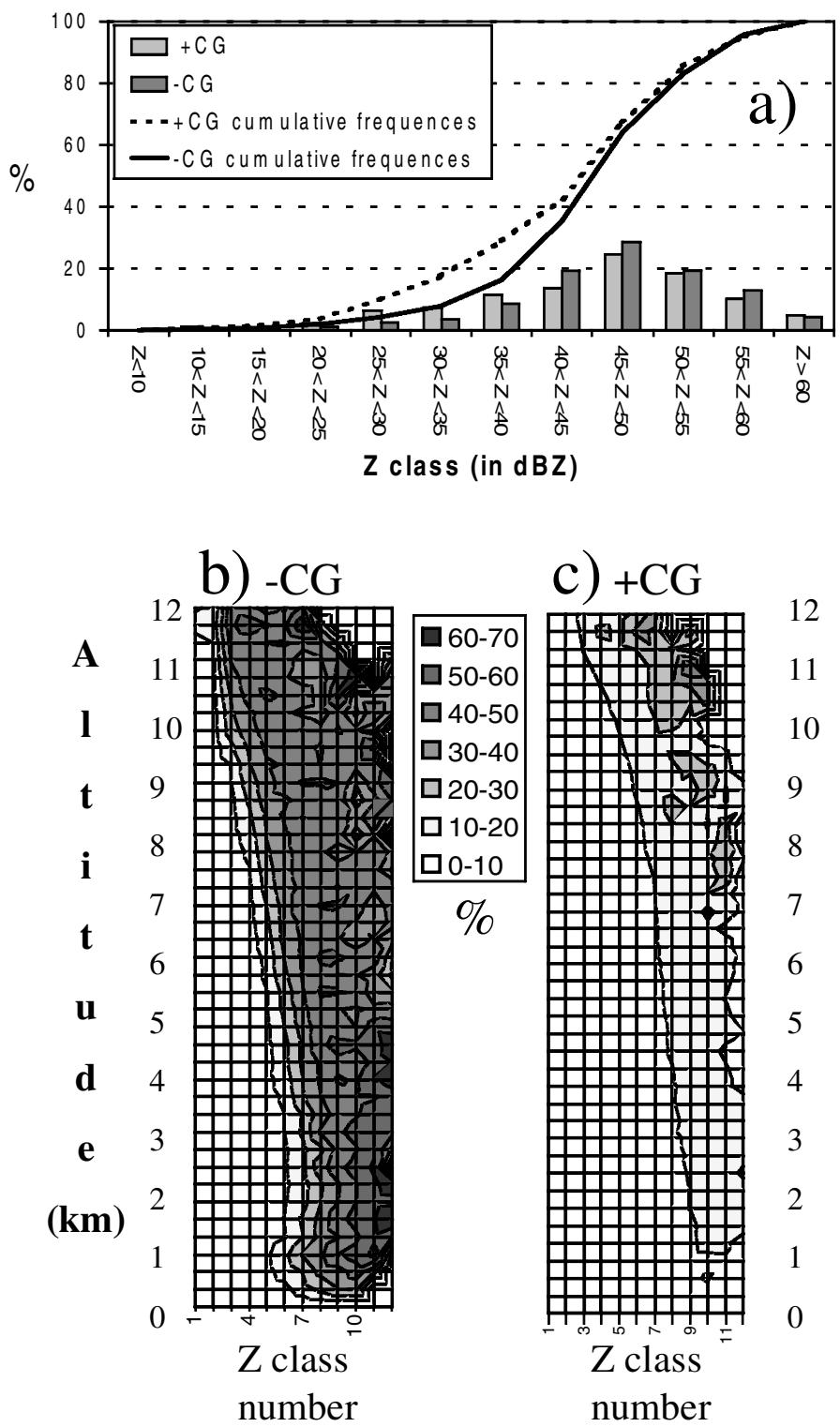

Figure 6. In IOP 2 a within a cylinder of radius $2 \mathrm{~km}$ : (a) relationships between radar reflectivity $(Z)$ and cloudto-ground lightning strikes (CGs) of each polarity, according to Method 1; (b) proportion of radar-reflectivity values associated with -CGs versus altitude according to Method 2; (c) as (b) but for +CGs. See text for details.

cases. According to Fig. 5, the proportion of GH particles decreases with altitude above $3 \mathrm{~km}$ whereas the proportion of GH associated with CG increases. For instance, at $11 \mathrm{~km}$ this proportion is $50 \%$ for $-\mathrm{CG}$ and $25 \%$ for $+\mathrm{CG}$. The more vertically developed a thundercloud is (or the higher GH can be found in a thundercloud) the more able it is to produce CGs. The peak for GH associated with $+\mathrm{CG}$ at a height of $1.2 \mathrm{~km}$ is not considered, because at altitudes lower than $2 \mathrm{~km}$ the presence of $\mathrm{GH}$ is too low to give realistic percentages. 

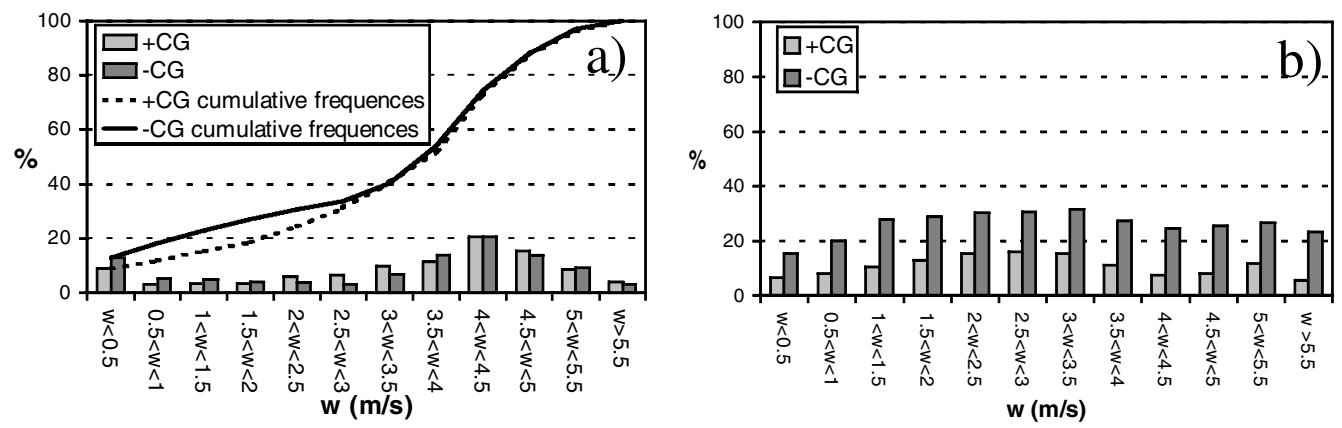

Figure 7. In IOP $2 \mathrm{a}$ within a cylinder of radius $5 \mathrm{~km}$ : (a) relationships between vertical velocity $w_{\max }$. and positive and negative cloud-to-ground lightning strikes (CGs) according to Method 1; (b) proportion of $w_{\max }$ values associated with positive and negative CGs according to Method 2. See text for details.

\section{(b) Correspondence with radar reflectivity}

According to Fig. 6(a) (Method 1), with $r=2 \mathrm{~km}, 50 \%$ of the CGs are associated with $Z_{\max }>45 \mathrm{dBZ}$ for $-\mathrm{CGs}$, and $Z_{\max }>44 \mathrm{dBZ}$ for + CGs. The best correspondence is obtained with the $45-50 \mathrm{dBZ}$ reflectivity class $(25 \%$ for $+\mathrm{CGs}$ and $28 \%$ for $-\mathrm{CGs}$ ), which only concerns less than $1 \%$ of the reflectivity values in our dataset. The + CGs seem to be better associated with low radar-reflectivity values than the - CGs: $12 \%$ of the - CGs and $23 \%$ of the + CGs are associated with $Z_{\max }<35 \mathrm{dBZ}$.

In Method 2, if the variation with altitude is considered (Fig. 6(b)), large reflectivity values ( $>55 \mathrm{dBZ}$ ) at altitudes lower than $5 \mathrm{~km}$ are associated with - CGs in more than $50 \%$ of the cases. Concerning the + CGs (Fig. 6(c)), the best correspondence (40-50\%) is obtained at high altitudes $(>10 \mathrm{~km}$ ), with $45<Z<50 \mathrm{dBZ}$. It is not possible to reach conclusions here regarding the origin of + CGs, but this is discussed in section 7 after the dynamical study of two specific cells in section 6 .

\section{(c) Correspondence with vertical velocity}

Here, the choice of $r=5 \mathrm{~km}$ is more adapted to the resolution of the vertical velocity estimation. From Method 1, Fig. 7(a) displays the frequency and cumulative frequency of - CGs and + CGs versus the maximum vertical velocity. As expected from section 3, the CGs are better distributed over the $w_{\max }$ scale than over the $Z_{\max }$ scale (Fig. 6(a)). 50\% of the CGs (without bias towards + or - ) occurred in areas with $w_{\max }>3.75 \mathrm{~m} \mathrm{~s}^{-1}$. The peak of the frequency curve is reached at $4<w_{\max }<4.5 \mathrm{~m} \mathrm{~s}^{-1}$ for both polarities. Low values of $w_{\max }\left(<2 \mathrm{~m} \mathrm{~s}^{-1}\right)$ are associated with - CGs rather than with $+\mathrm{CGs}$, and values ranging from 2 to $3.5 \mathrm{~m} \mathrm{~s}^{-1}$ are rather associated with + CGs. The percentages for the $w<0.5 \mathrm{~m} \mathrm{~s}^{-1}$ class are almost equal to those of the 3.5 to $4.0 \mathrm{~m} \mathrm{~s}^{-1}$ class. Conversely, from Method 2, according to Fig. 7(b), the peak of the frequency curve is reached at $3<w_{\max }<3.5 \mathrm{~m} \mathrm{~s}^{-1}$ for the -CGs $(32 \%)$ and at $2.5<w_{\max }<3.0 \mathrm{~m} \mathrm{~s}^{-1}$ for the +CGs $(16 \%)$.

\section{COMPARATIVE STUDY AND TEMPORAL CORRELATION OF THUNDERCLOUDS}

\section{(a) Comparative study}

The aspects studied in section 4 simultaneously took into account various regions of the active area and various stages of the thundercloud lifetime. In order to improve the understanding of the correlation, a study at the thundercloud-scale is undertaken. 


\begin{tabular}{|c|c|c|c|c|c|}
\hline & \multicolumn{4}{|c|}{17 Sept 1999} & \multirow{2}{*}{$\begin{array}{c}18 \text { Sept } 1999 \\
\text { Cell } 5\end{array}$} \\
\hline & Cell 1 & Cell 2 & Cell 3 & Cell 4 & \\
\hline CG counts & 249 & 398 & 342 & 623 & 104 \\
\hline$+\mathrm{CG}$ percentage $(\%)$ & 9 & 5 & 34 & 3 & 9 \\
\hline Time (beginning-end) UTC & $1500-1730$ & $1645-1945$ & $1645-1945$ & $2100-2315$ & $0000-0215$ \\
\hline Over mountains $(\mathrm{Y} / \mathrm{N})$ & Y & $\mathrm{N}$ & $\mathrm{Y}$ & $\mathrm{N}$ & $\mathrm{N}$ \\
\hline Hail & $\mathrm{N}$ & $\mathrm{Y}$ & $\mathrm{Y}$ & $\mathrm{N}$ & $\mathrm{N}$ \\
\hline$-\mathrm{CG}$ mean peak current $(\mathrm{kA})$ & -16.7 & -20 & -16 & -19.2 & -19.1 \\
\hline$+\mathrm{CG}$ mean peak current (kA) & 10.9 & 16.1 & 33.2 & 25.1 & 32.6 \\
\hline -CG multiplicity & 1.86 & 2.35 & 1.72 & 2.34 & 1.96 \\
\hline +CG multiplicity & 1.18 & 1.04 & 1.1 & 1.68 & 1.67 \\
\hline Maximal CG flash density $\left(\mathrm{km}^{-2}\right)$ & 2.2 & 2.44 & 1.28 & 2.04 & 0.72 \\
\hline Maximal 5-minute $-\mathrm{CG}$ rates & 20 & 31 & 28 & 44 & 12 \\
\hline Maximal 5-minute $+\mathrm{CG}$ rates & 6 & 4 & 12 & 2 & 2 \\
\hline Maximal $V_{\mathrm{f}}(30)\left(\mathrm{km}^{3}\right)$ & 1900 & 3800 & 6300 & $4520^{1}$ & $2180^{1}$ \\
\hline Maximal $V_{\mathrm{f}}(50)\left(\mathrm{km}^{3}\right)$ & 50 & 400 & 700 & $870^{1}$ & $96^{1}$ \\
\hline Maximal vertical velocity $\left(\mathrm{m} \mathrm{s}^{-1}\right)$ & 2.75 & 2.25 & 3.25 & 3.6 & 1.5 \\
\hline Maximal V(GH) $\left(\mathrm{km}^{3}\right)$ & 1100 & 2400 & 3600 & $1300^{1}$ & \\
\hline $30 \mathrm{dBZ}$ maximal echo top $(\mathrm{km})$ & 11 & 12 & $>12$ & 11 & 7.5 \\
\hline
\end{tabular}

${ }^{1}$ These values were only calculated at 30-minute intervals (Cells 4 and 5).

Cloud-to-ground lightning strike (CG) densities are calculated over pixels of $5 \times 5 \mathrm{~km}^{2}$. For Cells 1,2 and 3 , they were calculated at 15-minute intervals. By testing data for Cells 1, 2, and 3, the likely errors arising from having only 30-minute maximum values computed for Cells 3 and 4 were evaluated and found to be lower than $15 \%$. See text for further details.

Five individual thunderclouds are considered during IOP 2a, termed Cell 1 to Cell 5 henceforward. Four of them are indicated in Fig. 2, along with the total numbers of their CGs, while three of them are indicated in Fig. 3 with frequencies of CGs occurring over 15-minute periods. Their average characteristics are summarized in Table 1 . The fractional reflectivity volume $V_{\mathrm{f}}(\tau)$ is defined as:

$$
V_{\mathrm{f}}(\tau)=\int_{V_{\mathrm{c}}} f(x, y, z) \mathrm{d} v,
$$

with $f(x, y, z)=1$ if $Z(x, y, z) \geq \tau$ and $f(x, y, z)=0$ if $Z(x, y, z)<\tau$, where $V_{\mathrm{c}}$ is the volume of the cell, and $v$ is volume.

The particle volume $V(H)$ is calculated for each particle type given in section 2 as:

$$
V(H)=\int_{V_{\mathrm{c}}} g(x, y, z) \mathrm{d} v,
$$

with $g(x, y, z)=1$ if the particle type $H$ is dominant and $g(x, y, z)=0$ otherwise.

Although the cells evolved in the same environment and nearly at the same time (as Cell 2 and Cell 3), they exhibited various CG polarities, densities, and rainfall amounts. Most of the cells had a strong vertical development (with a $30 \mathrm{dBZ}$ echo top at an altitude of more than $11 \mathrm{~km}$ ) and vertical velocities $w_{\max }$ exceeding $2.25 \mathrm{~m} \mathrm{~s}^{-1}$. As explained in section 2, the retrieved vertical velocities do not correspond to the real updraught magnitude in thunderclouds but their absolute values are of no interest here, they are simply used to compare the cells. From Table 1, Cell 5 appears different from the others in terms of vertical dynamics (smaller vertical velocities and vertical extent) and $C G$ activity (weaker rates and number). Furthermore, its fractional volume $V_{\mathrm{f}}(30)$ is comparable to that of Cell 1 . Cell 1 is characterized by a small $V_{\mathrm{f}}(50)$ compared to others, but its vertical development is comparable to more active cells and its CG activity 

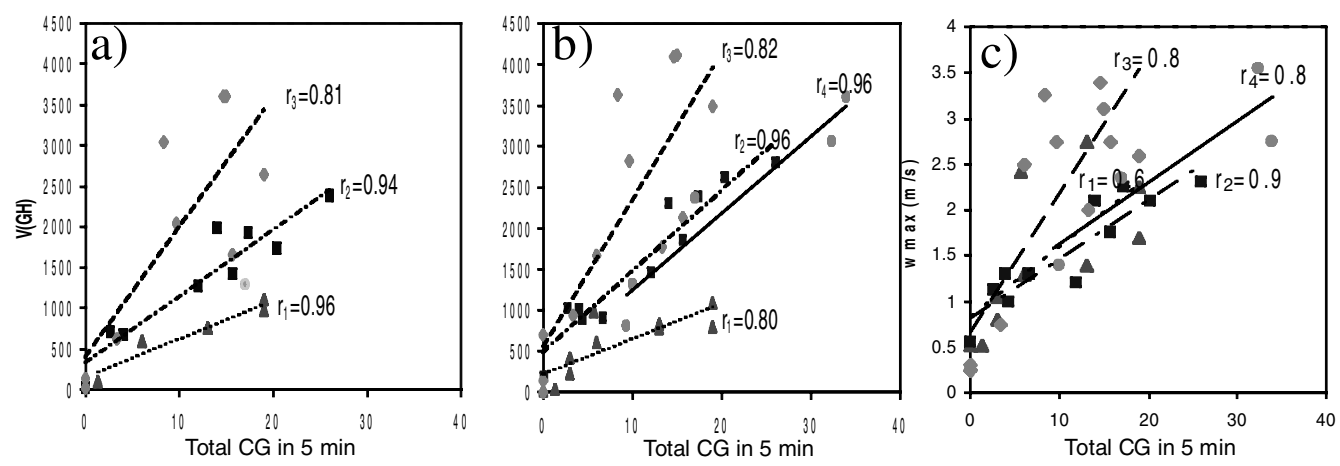

Figure 8. In IOP 2a correlations between 5-minute total cloud-to-ground lightning strike (CG) rates and: (a) fractional graupel/hail particle volume, $V(\mathrm{GH})$; (b) fractional volume $V_{\mathrm{f}}(35)$; (c) vertical velocity $w_{\max }$. Fiveminute $\mathrm{CG}$ rates are taken as an average over three periods of 5 minutes. Sample points are solid triangles for Cell 1, solid squares for Cell 2, grey diamonds for Cell 3, and grey circles for Cell 4. Linear correlation coefficients are given as $r_{i}$ where $i$ is the cell number. See text for details.

is just a little weaker with $249 \mathrm{CGs}$ and a maximum density of $2.2 \mathrm{~km}^{-2}$. Its CG activity seems to be concentrated in time and space within a period of intense convective activity. Cell 3 presented an especially high + CG percentage (34\%) compared to other cells, as well as the strongest vertical development $(12 \mathrm{~km})$. However, that cell did not produce the largest CG number or density.

\section{(b) Temporal correlations}

For each cell, the parameters analysed in the time correlation are: $\mathrm{CG}$ rates, fractional volumes $V(\mathrm{GH})$ and $V_{\mathrm{f}}(35)$, and the maximum vertical velocity $w_{\max }$. They were calculated over 15-minute intervals. +CGs and -CGs were also distinguished. Correlations were better with $-\mathrm{CG}$ s than with $+\mathrm{CGs}$, and still better with total $\mathrm{CG}$ rates. Thus Fig. 8 only shows correlations with total $\mathrm{CG}$ rates. Concerning $V_{\mathrm{f}}(\tau)$, various values of $\tau$ were tested, and the best results were found to be obtained with $\tau=35$ or $40 \mathrm{dBZ}$. Figures 8(a), (b) and (c) display the distribution of $V(\mathrm{GH}), V_{\mathrm{f}}(35)$ and $w_{\max }$, respectively, versus the CG rates for Cells 1,2,3, and 4. The linear correlation coefficients, $r$, are plotted in each graph. They are calculated according to:

$$
r=\frac{\overline{(x y)}-(\bar{x})(\bar{y})}{\sigma_{x} \sigma_{y}},
$$

where the overbar represents a mean value, and $\sigma$ the standard deviation.

Because of its small number of points, the correlations for Cell 5 were not statistically significant and are thus not shown in Fig. 8. The same applies for Cell 4 in Fig. 8(a). The correlation is high for each individual cell (between 0.68 and 0.96), but would be lower if all cells were considered together. The slopes of the curve fittings are different; each cell thus seems to have its own efficiency in the production of CGs. However, for Cells 2 and 4 the slopes are quite close in both Figs. 8(b) and (c). The most efficient producer of CGs is Cell 1 , which with lower $V(\mathrm{GH})$ and $V_{\mathrm{f}}(35)$ produces a large quantity. Tabary (2002) explained that this cell, situated over the mountains and linked to orographic forcing by the Monte Rosa mountain, had different microphysical characteristics compared to the others. The air originated from higher levels $(2000 \mathrm{~m})$, and the lifted air parcels reached their condensation level above the freezing level which led to the formation of snow. Cell 1 is the only one presented here which evolved entirely 
above the mountains. For the other cells, the lifted air parcels first produced condensation in the form of water droplets which may have frozen when further lifted above their freezing level. In Cell 1, S-Pol polarimetric observations showed that DS and HC represented more than $54 \%$ of the particles, compared with $40 \%$ for the other cells. Ice crystals are known to be one of the necessary ingredients acting in the non-inductive charging processes (Takahashi et al. 1978). This could have resulted in enhanced CG activity. Another possible explanation is that for this cell, because of the topography, the ground was even closer to the main cloud charge which could favour CGs.

The correlations are lower for Cell 3 compared with the other cells. This cell, the most vigorous in terms of $V(\mathrm{GH})$ and echo tops, was the least efficient CG-producing cell in the three curve fittings (Figs. 8(a), (b) and (c)). It produced a lot of + CGs in the second part of its lifetime and a good deal of hail, and thus it may have been different from the other cells. This cell is examined in detail in section 6 .

With $V_{\mathrm{f}}(35)$ (Fig. 8(b)) similar correlations can be seen to those in Fig. 8(a). This can be explained by the fact that GH is largely responsible, with DS, for reflectivities greater than $35 \mathrm{dBZ}$. With $w_{\max }$ (Fig. 8(c)) correlations are slightly lower (as inferred from sections 3 and 4). All the cells displayed the same behaviour, with the exception once again of Cell 3.

\section{EXTENSIVE AND COMPARATIVE STUDY OF CELLS 2 AND 3}

A comparative study of Cells 2 and 3 could help in understanding what parameters govern the production of + CGs. These cells evolved nearly at the same time, $50 \mathrm{~km}$ apart, but their electrical signatures were very different: Cell 2 produced large amounts of - CGs whereas Cell 3 produced a high proportion of + CGs (about $34 \%$ on average).

Figure 9 shows horizontal cross-sections of radar reflectivity and wind at 1815 UTC. Figure 10 shows the time evolution of $C G$ rates, $V_{\mathrm{f}}(35), V_{\mathrm{f}}(45), V_{\mathrm{f}}(55), V(\mathrm{GH}), V(\mathrm{HL})$, and $w_{\max }$ for both cells, and Fig. 11 displays vertical cross-sections through Cells 2 and 3 at 1815 UTC for (a) radar reflectivity, (b) particle type, and (c) vertical velocity.

\section{(a) Cell 2}

Cell 2 developed at 1645 UTC while entering a valley shown on the relief map Fig. 9(d). The low-level moist airflow was south-easterly (Fig. 9(a)). This cell, steered by the mid-tropospheric winds (Fig. 9(b)), moved north-eastwards towards the end of the valley, and was finally trapped by the relief. It remained quasi stationary for two hours and consequently led to a locally large amount of rainfall $(70 \mathrm{~mm})$ and high CG densities $\left(2.3 \mathrm{~km}^{-2}\right)$. At $1900 \mathrm{UTC}$, it crossed the high ground and moved southeastwards over the plain, merging with other cells at 1945 UTC making it impossible to identify after that time. As shown in Table 1, this cell produced 309 CGs with only $15+$ CGs. As mentioned in section 2, because they exhibit low peak currents (Table 1) these +CGs may be distinguished by the system from ICs (Pinto et al. 1999; Théry 2001). Figure 10(a) shows that the activity of Cell 2 exhibited two different stages, the first one with low CG rates before 1800 UTC and the second with high CG rates after 1800 UTC. This characteristic of the evolution of CG activity is common to all cells studied for IOP 2a except for Cell 3, which exhibited a first stage with stronger CG rates (Fig. 10(b)).

During its first stage, between 1645 and 1800 UTC, the CG rates produced by Cell 2 were relatively low $(<10 \mathrm{CG}$ in a 5-minute period). The vertical development stayed below $11 \mathrm{~km}$ and $w_{\max }$ was weak $\left(1.25 \mathrm{~m} \mathrm{~s}^{-1}\right)$. Yet, despite this the particle-type classification algorithm showed some hail between 1715 and 1730 UTC. 

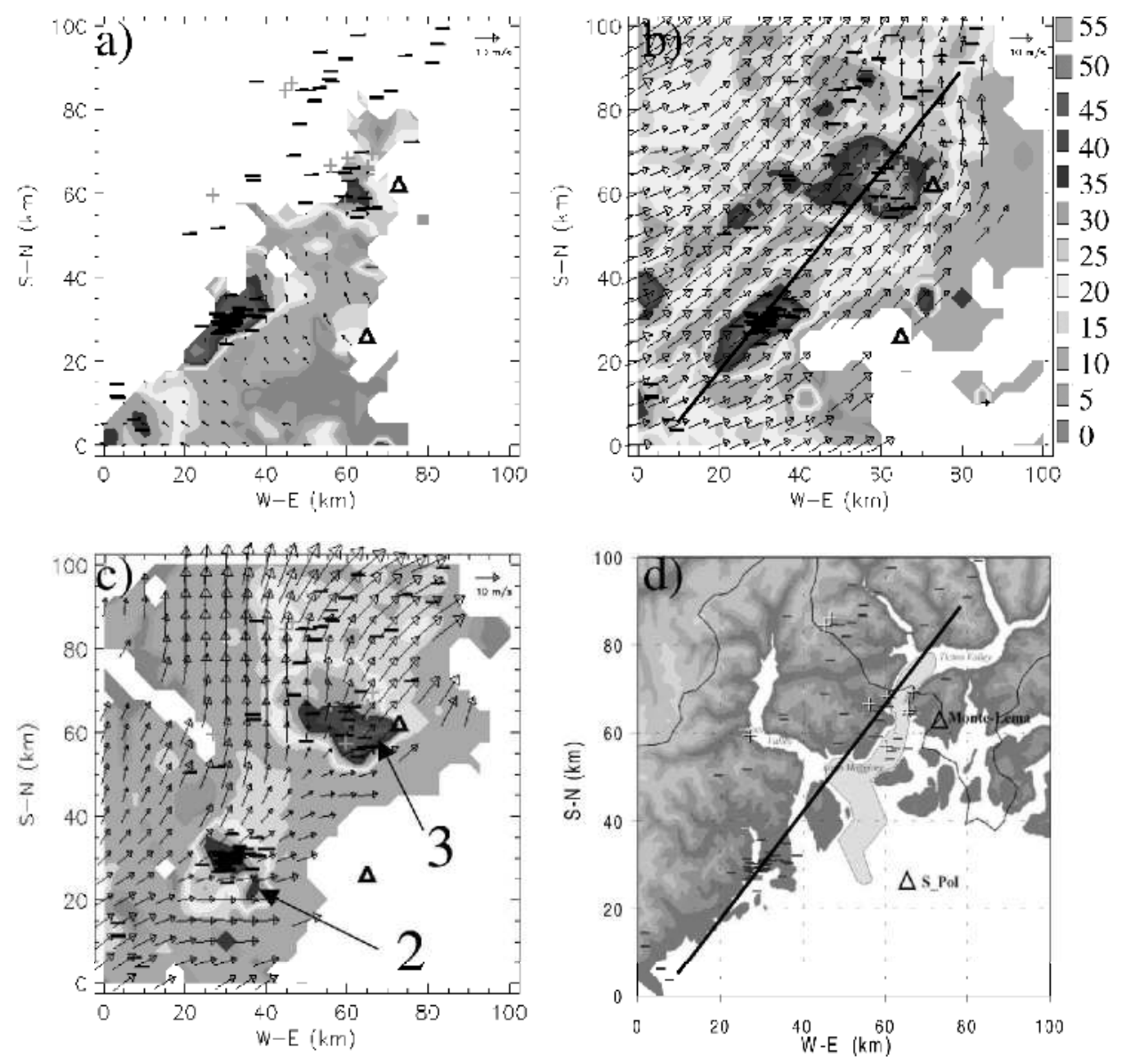

Figure 9. In IOP 2a 17 September 1999 horizontal cross-sections of radar reflectivity (dBZ, grey scale) and horizontal wind fields (reference vector in top right-hand corner) at heights: (a) $1.2 \mathrm{~km}$, (b) $5.1 \mathrm{~km}$, and (c) $9 \mathrm{~km}$, all at 1815 UTC, and with positive $(+)$ and negative $(-)$ cloud-to-ground lightning strikes (CGs) between 1815 and 1830 UTC superimposed. (d) Shows the topography using a grey scale (500 m intervals) and also CGs. The black lines in (b) and (d) represents the axis of the vertical cross-section in Fig. 11. The locations of Cells 2 and 3 are shown in (c). See text for further details.

During the second stage, after 1800 UTC, the activities of Cell 2 increased as shown by $w_{\max }$, CG rates and $V(\mathrm{GH})$ (Fig. 10(a)). Between 1645 and 1915 UTC the activities mostly displayed a good correlation, except temporarily between 1830 and 1845 UTC when CG rates decreased while the other activities continued to increase. The parameters peaked at the same time, 1845 UTC.

\section{(b) Cell 3}

Cell 3 was the most active in terms of $V_{\mathrm{f}}(30), V(\mathrm{GH})$, and $+\mathrm{CG}$ rates. The lowlevel southerly flow was about $10 \mathrm{~m} \mathrm{~s}^{-1}$ around the cell. Cell 3 developed at 1645 UTC over the entrance of a valley on the northern side of Lago Maggiore, where the moist southerly flow was forced to rise by the mountains after crossing the lake (Fig. 3(d)). The cell first moved northwards, while expanding over the mountains (tops about $2000 \mathrm{~m}$ ). At 1800 UTC it began moving eastwards towards the Monte-Lema, then moved up the Ticino Valley at $15 \mathrm{~km} \mathrm{~h}^{-1}$ and decayed after 1945 UTC. According to Fig. 10(b), 

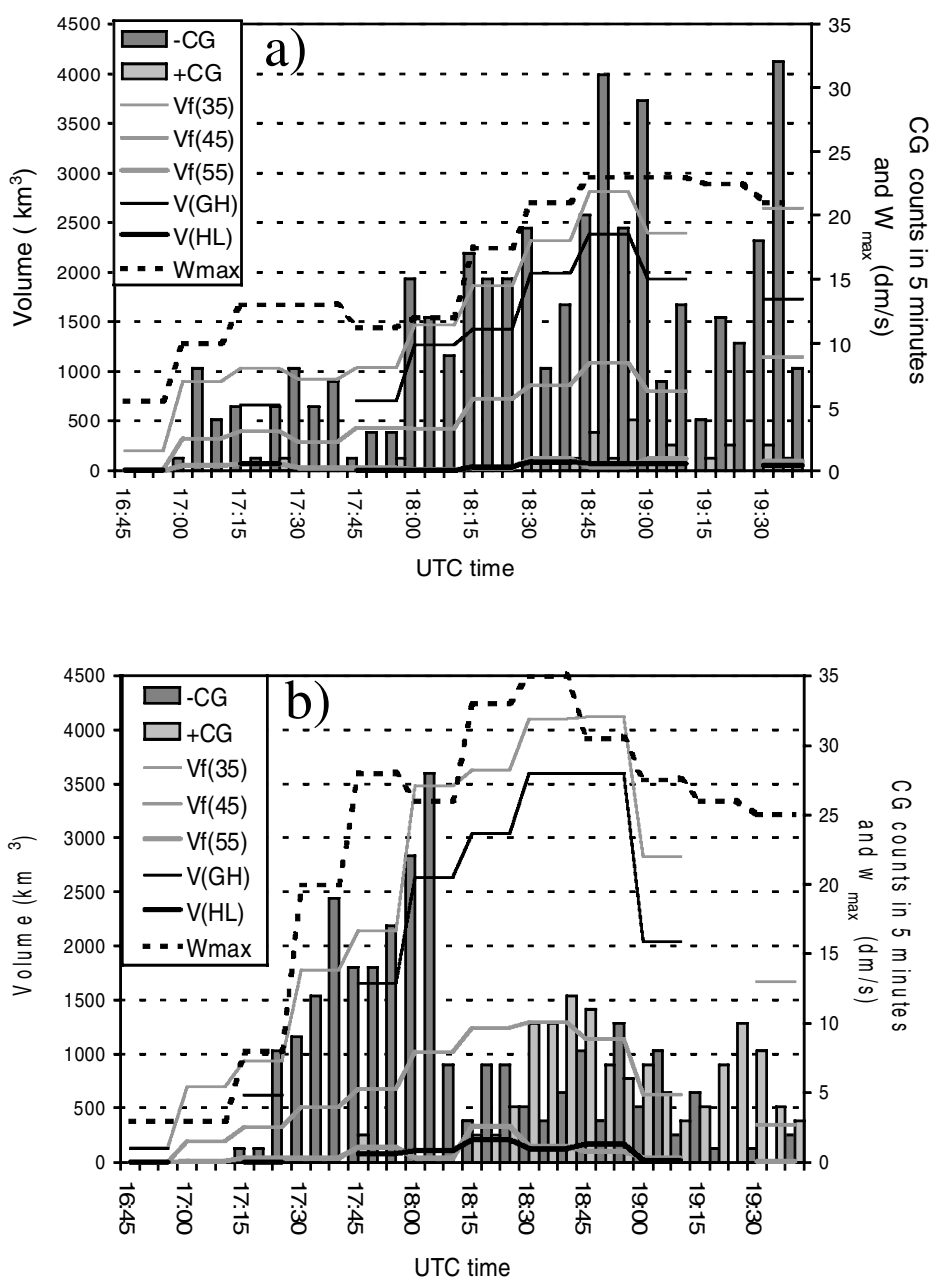

Figure 10. Time evolution of dynamical, electrical, and microphysical characteristics of two individual thunderclouds during IOP 2a on 17 September 1999: (a) Cell 2, and (b) Cell 3. Some parameters were not available around 1915 UTC because of the lack of radar data. See text for details of the parameters and discussion.

this cell exhibited two different stages, but unlike other cells CG rates were greater in the first.

During its first stage, between 1645 and 1800 UTC, $w_{\max }, V_{\mathrm{f}}(35)$, and $V(\mathrm{GH})$ all increased. The cell was over the mountains. CG rates were relatively high, peaking at 27 in a 5-minute period at 1805 UTC. The CGs essentially had negative polarity. By observing various vertical cross-sections through this cell (not shown) it is seen that the cell ceased developing at 1800 UTC for a short time. A slight temporary decrease of $w_{\max }$ was also observed at that time, associated with the peak CG rate. Suddenly at 1810 UTC, although $w_{\max }, V_{\mathrm{f}}(35)$ and $V(\mathrm{GH})$ continued to increase, $\mathrm{CG}$ activity drastically decreased. At the same time the cell stretched vertically with echo tops higher than $12 \mathrm{~km}$ at 1830 UTC. After $1810 \mathrm{UTC}$, +CGs became predominant. The polarity switch was clearly associated with the increases in vertical development and vertical velocity (1815 UTC); $w_{\max }$ was greater than $3 \mathrm{~m} \mathrm{~s}^{-1}$ between 1815 and 1900 UTC. When the + CG rate was at its maximum (1840 UTC) so was the vertical development. It seems that this was a really severe thunderstorm rarely documented in Europe. At the end 

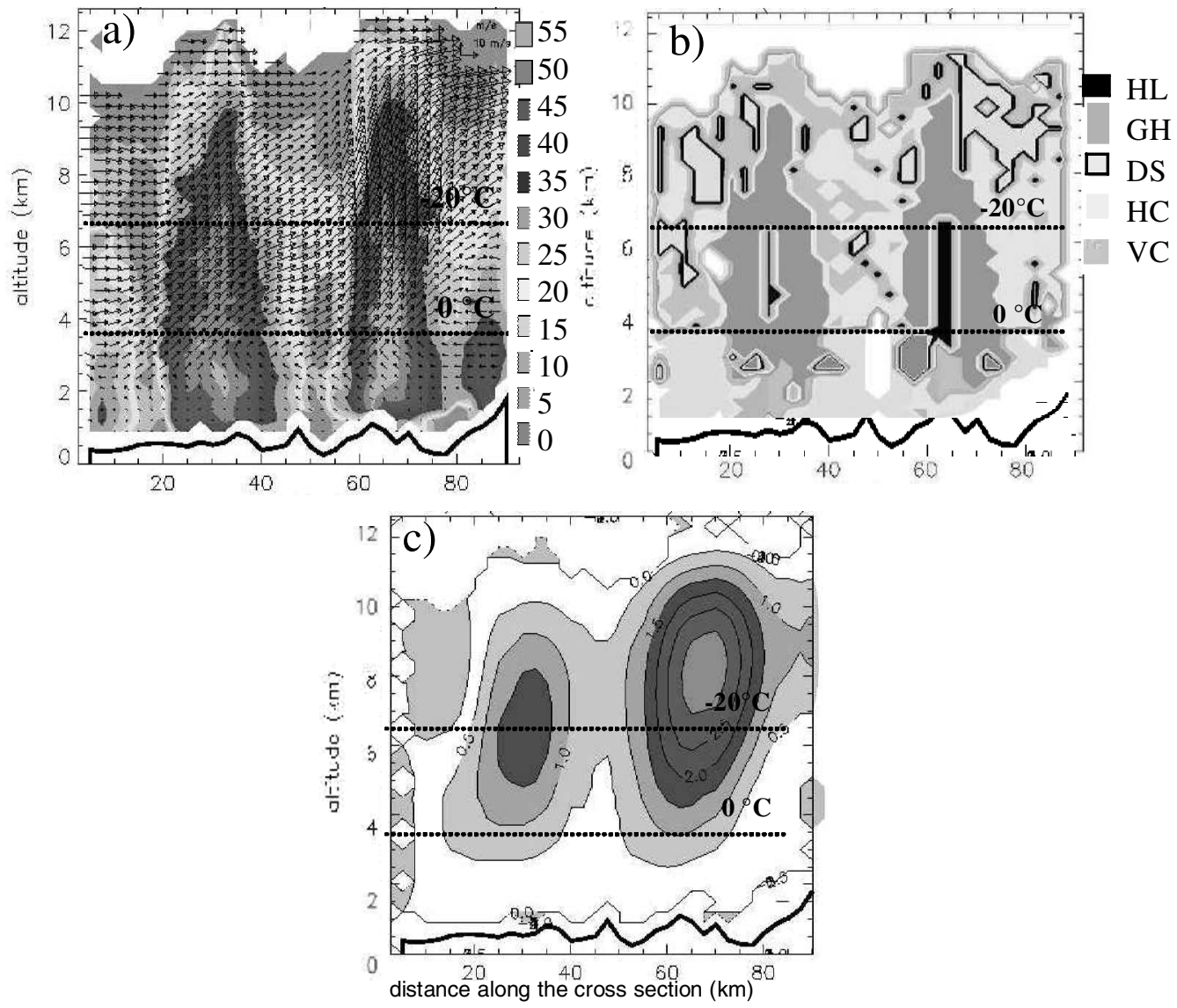

Figure 11. Vertical cross-sections through Cell 2 (left) and Cell 3 (right) during IOP 2a on 17 September 1999 at 1815 UTC along the line shown in Fig. 9(b): (a) radar reflectivity (dBZ) and wind (given as vectors in plan view); (b) particle type (hail HL, graupel/hail mixture GH, dry snow DS, horizontally aligned crystals HC, vertically aligned crystals VC); and (c) vertical velocity $\left(\mathrm{m} \mathrm{s}^{-1}\right.$, contour interval 0.5$)$. See text for further details.

of the documented evolution the +CG activity was still strong and localized, but the thundercloud then left the study domain.

\section{DISCUSSION}

Our observations are in agreement with the non-inductive charging process based on graupel-ice interaction observed in laboratory experiments (Takahashi 1978; Jayaratne et al. 1983; Saunders et al. 1991) and, as in our study, with in situ radar measurements (Dotzek et al. 2001). GH was frequently observed to be the dominant particle around CGs. As explained in section 2, the particle-type algorithm provides the dominant particle type for each grid point. Therefore, whilst classified as $\mathrm{GH}$ it also contained $\mathrm{HC}$ or VC, and graupel-ice interaction can have occurred in the volume. GH without any CGs around was also observed. If the charge is separated by graupel-ice interaction, it needs time to create an electric field sufficient to produce the first CG; thus GH appears before the first CG. This can be seen for Cell 3, for example, which exhibited $V(\mathrm{GH})$ $\neq 0$ at 1645 UTC whereas the first CG appeared at 1715 UTC. It can explain the results in Fig. 5. Because the correlation between CGs and GH was seen to increase with the 
altitude, it can be said that the more vertically developed a thundercloud, the more it is able to produce CGs.

How is it possible to explain why CG rates suddenly decreased for Cell 3 ?

(i) At 1800 UTC, the cell left the mountains and reached the Ticino valley. Under the cell the ground was then flat, and farther than before from the electrically charged cloud; CGs were thus less favoured.

(ii) The decrease in CG rates could also be linked to the presence of hail. After 1800 UTC, $V$ (HL) increased and stayed relatively high until 1900 UTC. Recently, Lang et al. (2000) reported an anticorrelation between hail and -CG flash production. The two storms they studied in Colorado (USA) were unusual in that they produced very few CGs of either polarity during large parts of their lifetime. Other works have pointed out the decrease of IC and CG lightning activity with hail production (Seity et al. 2001), and others have documented the association of dominant +CG (compared with -CG) production during hail (MacGorman and Burgess 1994; Carey and Rutledge 1998). The quasi-spherical shape of hailstones might not favour lightning initiation because discharge triggering needs an electric field value larger than the usually measured values (Coquillat and Chauzy 1994). The freezing droplets associated with hail production could also explain the enhancement of vertical velocities after 1810 UTC, thanks to the transfer of latent-heat energy.

Another explanation is necessary concerning the predominant + CGs and the polarity switching for Cell 3 at 1815 UTC. +CG rates greater than two a minute, as at 1840 UTC, were quite exceptional, and the +CG proportion was very high (100\% between 1925 and 1930 UTC). Studies reporting dominant ground-flash polarity switching (Rust et al. 1985; Seimon 1993; Smith et al. 2000) are quite rare, and have only been conducted in the USA. In these cases, unlike our Cell 3, the CG polarity was first positive and then switched to negative. MacGorman and Burgess (1994) sometimes observed initially negative polarity and more than once observed switching. Both cases were associated with severe weather (hail and/or tornadoes). The study of Seimon (1993) concerned a vigorous supercell producing a F5 tornado. Smith et al. (2000) suggested that the CG polarity-reversal process may be initiated by rapid updraught intensification. The case of Cell 3 presented here does not seem to be a supercell, but may still represent the first observation reported in Europe of such polarity switching. Moreover, with MAP radar data this case is very well documented compared to other studies. Seimon (1993) and Zajac and Rutledge (2001) in a climatological study over USA, observed 'unusual' -CG multiplicities (numbers of strokes per CG) during the +CG producing stage of the supercell. In Table 1, the mean -CG multiplicity and peak currents given by Cell 3 are 1.72 and $-16 \mathrm{kA}$ respectively; these are low compared with the other cells and values given by other studies. Seity et al. (2001), in a study of 21 stormy days in the south-western part of France, found daily-averaged values for -CG multiplicity ranging from 1.7 to 3.0 , and for $+\mathrm{CG}$ multiplicity from 1 to 1.47 . Concerning the peak current, usual values range from 20 to $30 \mathrm{kA}$ for-CGs (Berger et al. 1975; Orville et al. 1997; Sheridan et al. 1997; Pinto et al. 1999; Seity et al. 2001), and from 40 to $50 \mathrm{kA}$ for +CGs (Sheridan et al. 1997; Seity et al. 2001). Cell 3 produced seven +CGs with peak-current greater than $80 \mathrm{kA}$ (one with $120 \mathrm{kA}$ ), and three lower than $10 \mathrm{kA}$. The minimum $-\mathrm{CG}$ peak current was $-50 \mathrm{kA}$ and 11 strokes were lower than $-30 \mathrm{kA}$. By comparison, for Cell 2 the maximum + CG peak current was $40 \mathrm{kA}$ with two strokes below $10 \mathrm{kA}$ (these last strokes may have been IC flashes according to Pinto et al. (1999) and Théry (2001)) and $-60 \mathrm{kA}$ for -CGs. In Table 2 both stages of CG production are distinguished for Cell 3 (the -CG stage before 1815 UTC, and the +CG stage after 
TABLE 2. ClOUd-TO-GROUND LIGHTNING STRIKE (CG) PEAK CURRENTS AND MULTIPLICITY DURING THE TWO STAGES OF CELLS 2 AND 3

\begin{tabular}{llccccrr}
\hline & $\begin{array}{c}+\mathrm{CG} \\
\text { peak current }\end{array}$ & $\begin{array}{c}-\mathrm{CG} \\
\text { peak current }\end{array}$ & $\begin{array}{c}+\mathrm{CG} \\
\text { multiplicity }\end{array}$ & $\begin{array}{c}-\mathrm{CG} \\
\text { multiplicity }\end{array}$ & $\begin{array}{c}+\mathrm{CG} \\
\text { counts }\end{array}$ & $\begin{array}{c}-\mathrm{CG} \\
\text { counts }\end{array}$ \\
\hline \multirow{2}{*}{ Cell 3 } & First stage & 11.2 & -17.7 & 1 & 1.98 & 2 & 152 \\
& Second stage & 33.5 & -12.5 & 1.13 & 1.16 & 115 & 73 \\
Cell 2 & First stage & 17.2 & -22.7 & 1 & 2.18 & 2 & 51 \\
& Second stage & 16 & -19.6 & 1.05 & 2.37 & 19 & 326 \\
\hline
\end{tabular}

Mean peak currents are expressed in kA.

1815 UTC). The low -CG multiplicity and peak current during the $+\mathrm{CG}$ producing stage of Cell 3 (stage 2) is also observed. Cell 2 does not exhibit such a pronounced contrast between its two stages. According to Seimon (1993) and Zajac and Rutledge (2001) low -CG multiplicities seem to be a characteristic of positive-stroke dominant thunderstorms. The main negative charge in Cell 3 should be weakened. These last two studies also describe abnormally high $+\mathrm{CG}$ peak current during $+\mathrm{CG}$ producing stages. For Cell 3 this seems not to have been the case.

The origins of the high $+\mathrm{CG}$ produced by Cell 3 may be queried. According to various studies (Carey and Rutledge 1998; MacGorman et al. 2001) three theories are advanced to explain the abnormally high $+\mathrm{CG}$ production of some thunderclouds. These theories differ in the location of the positive charge in the cloud: the top of the cloud according to the dipole model; the lower part according to the tripole model; or the middle part of the cloud according to the inverted tripole model.

(i) The tilted dipole (MacGorman and Nielsen 1991; Branick and Doswell 1992) belongs to the first of these theories. It does not seem to correspond with the present study, because the strong reflectivity distribution is rigorously vertical (Fig. 11(a)) and +CGs are collocated with high radar-reflectivity values. Moreover, this mechanism does not explain the near-zero -CG production for Cell 3 during the second stage of its life.

(ii) Carey and Rutledge (1998) proposed the theory that rainfall removes the main negative charge, which leaves the positive one alone at the cloud top. This mechanism explains the diminution of $-\mathrm{CG}$ rates but is still ambiguous. Although Cells 2 and 3 exhibited comparable rainfalls the first only produced -CGs and the second a majority of + CGs during the second stage of their lifetimes.

(iii) Inverted-polarity thunderstorms, with a main mid-level positive charge and upper and lower negative charges, can produce predominantly +CGs. Such charged thunderclouds have been observed recently in the USA, in areas such as the northcentral USA from the Colorado-Kansas border to western Minnesota (MacGorman et al. 2001; Zajac and Rutledge 2001). At the moment the reasons for this kind of charge structure remain unclear. A key to this is whether inverted polarity storms are actually non-inverted thunderstorms with 'extra' regions of charge in the vertical axis.

(iv) Theories on an enhanced lower positive-charge region (MacGorman and Nielsen 1991; Williams et al. 1991) are based on +CGs originating from the lower part of thunderclouds. They are often associated with very intense thunderstorms (Seimon 1993; MacGorman and Burgess 1994; Stolzenburg 1994; Carey and Rutledge 1998). Various theories have been proposed to explain this positive-charge generation (Carey and Rutledge 1998). The most efficient one seems to be associated with the noninductive charging processes (Takahashi 1978; Jayaratne et al. 1983; Saunders et al. 1991). At temperatures $(T)$ higher than about $-10^{\circ} \mathrm{C}$, laboratory studies from both Takahashi (1978) and Saunders et al. (1991) agree that if the liquid-water content 
is large enough, graupel is positively charged after contact with an ice crystal. The volumes of $\mathrm{GH}$ were calculated for Cells 2 and 3, and that for Cell 3 appeared to be $60 \%$ greater. Thus, this could have led to a more developed lower-level positive charge for Cell 3. Moreover, vertical velocities were inferred from radar measurements to be greater for Cell 3, and hail was found to be more widespread in this cell. These enhanced vertical velocities increase the number of collisions between graupel and ice crystals, and also increase the sizes of the ice or snow particles (as inferred from greater $V_{\mathrm{f}}(\tau)$ from Fig. 10), which produces more charge per collision (MacGorman and Rust 1998). Thus vertical velocities reinforced the lower positive charge. Although all the parameters, especially the liquid-water content are not known, this explanation of a lower positive-charge structure creating +CGs seems to be the most realistic, according to the present observations. The development of the lower positive charge is consistent with the decrease in -CGs rates observed in Cell 3. For the other cells, $V(\mathrm{GH})$ at $T>-10{ }^{\circ} \mathrm{C}$ and/or $w$ were not sufficient to create a well-developed lower positivecharge region sufficient to initiate $+\mathrm{CGs}$.

\section{Conclusion}

In this study, different aspects of the relationships between CG activity and dynamical and microphysical characteristics of thunderclouds are presented, using MAP data of IOP 2 a (17 and 18 September 1999). This IOP produced many tall thunderclouds (30 dBZ echo tops up to $12 \mathrm{~km}$ ), and large amounts of CGs. The data were provided by Doppler/Polarimetric radars and by a CG detection network. Averaged statistical properties were first analysed, followed by studies of individual cells. The most important findings can be summarized as follows:

- CG production is highly correlated with the presence of a graupel-hail mixture.

- A further spatial correlation is observed between CG production and strong radarreflectivity values; +CGs (-CGs) are observed to be highly correlated with large reflectivity values at altitudes greater than $10 \mathrm{~km}$ (lower than $5 \mathrm{~km}$ ).

- While CGs seem to occur in areas with large radar-reflectivity values, they are not exactly collocated with the largest vertical velocities. Therefore, they could be associated with large precipitation particles (Williams et al. 1989; Coquillat and Chauzy 1994).

- CG flash rates are very well correlated with the volume of graupel-hail mixture in the cell and with the volume having radar reflectivity greater than $35 \mathrm{dBZ}$ (linear correlation coefficients greater than 0.8 ). Correlations with vertical velocity are slightly lower.

- The evolutions of two cells were compared, one giving a large majority of -CGs, and the other a high proportion of + CGs $(61 \%)$ during its second stage of activity (when producing large amounts of hail). A well-developed lower-level positive charge created by non-inductive mechanisms could explain the production of $+\mathrm{CGs}$.

More research is necessary to substantiate these statements. Thunderclouds producing strong $+\mathrm{CG}$ rates may be severe storms. Conversely, a severe storm is not always associated with large proportions of + CGs. Nevertheless, the identification of dominant 'positive' storms in real time could be useful in forecasting severe weather.

\section{ACKNOWLEDGEMENTS}

The authors would like to thank the ALDIS Society for providing CG data, and all participants in the MAP experiment, especially Evelyne Richard, Frank Roux from the 

Chong and Jean-François Georgis from the Laboratoire d'Aérologie for their technical help on radar data processing.

Berger, K., Anderson, R. B. and Kröninger, $\mathrm{H}$.

Bougeault, P., Binder, P., Buzzi, A., Dirks, R., Houze, R.,

Kuettner, J., Smith, R. B., Steinacker, R. and Volkert, H.

Branick, M. L. and

Doswell, C. A. III

Carey, L. D. and Rutledge, S. A.

Chong, M., Georgis, J.-F.,

Bousquet, O., Brodzik, S.,

Burghart, C., Cosma, S.,

Germann, U., Gouget, V.,

Houze, R. A., James, C.,

Prieur, S., Rotunno, R.,

Roux, F., Vivekanandan, J. and Zeng, Z. X.

Christian, H., Blakeslee, R. J.,

Boccippio, D. J., Boeck, W. L.,

Buechler, D. E.,

Driscoll, K. T.,

Goodman, S. J., Hall, J. M.,

Koshak, W. J., Mach, D. M. and Stewart, M. F.

Coquillat, S. and Chauzy, S.

Dotzek, N., Höller, H., Théry, C. and Fehr, T.

Engholm, C. D., Williams, E. R. and Dole, R. M.

Frei, C. and Schär, C.

Iorio, R. and Ferrari, D.

Jacobson, E. A. and Krider, E. P.

1976

Jayaratne, E. R., Saunders, C. P. R. and Hallett, J.

Lang, T. J., Rutledge, S. A., Dye, J. E., Venticinque, M., Laroche, P. and Defer, E.

MacGorman, D. R. and Burgess, D. W.

MacGorman, D. R. and Nielsen, K. E.

MacGorman, D. R. and Rust, W. D. 1998

MacGorman, D. R., Rust, W. D., Detwiller, A., Heldson, J., Krehbiel, P., Rison, W., Thomas, R., Rutledge, S., Carey, L., Weisman, M. and Miller, J.

2001

\section{REFERENCES}

1975 Parameters of lightning flashes. Electra, 41, 23-37

The MAP Special Observing Period. Bull. Am. Meteorol. Soc., 82, 433-462

1992 An observation of the relationship between supercell structure and lightning groud strike polarity. Weather Forecasting, 7, 143-149

1998 Electrical and multiparameter radar observations of a severe hailstorm. J. Geophys. Res. 103, D12, 13979-14000

2000 Real-time wind synthesis from Doppler radar observations during the Mesoscale Alpine Programme. Bull. Am. Meteorol. Soc., 81, 2953-2962

'Global frequency and distribution of lightning as observed by the Optical Transcient Detector (OTD)'. Pp. 734-737 in Proceedings of the 11 th international conference on atmospheric electricity, Guntersville, Alabama. NASA, Marshall Space Flight Center, USA

1994 Computed conditions of corona emission from raindrops. J. Geophys. Res., 99, 16897-16906

2001 Lightning evolution related to radar-derived microphysics in the 21 July 1998 EULINOX supercell storm. Atmos. Res., 56, 334-354

1990 Meteorological and electrical conditions associated with positive cloud-to-ground lightning. Mon. Weather Rev., 118, 470-487

1998 A precipitation climatology of the Alps from high resolution raingauge observations. Int. J. Climatol., 18, 873-900

1997 'Keraunic characterization of mountainous and flat zones in North Italy based on a two-year lightning detection system operation'. Pp. 21-25 in Proceedings of the conference on lightning and mountains'97. Soc. des Electriciens et des Electroniciens (SEE), Chamonix Mont Blanc, France

Electrostatic field changes produced by Florida lightning. J. Atmos. Sci., 33, 103-117

1983 Laboratory studies of the charging of soft hail during ice crystal interactions. Q. J. R. Meteorol. Soc., 109, 609-630

2000 Anomalously low negative cloud-to-ground lightning flash rates in intense convective storms observed during STERAO-A. Mon. Weather Rev., 128, 160-173

1994 Positive cloud-to-ground lightning in tornadic storms and hailstorms. Mon. Weather Rev., 122, 1671-1697

1991 Cloud-to-ground lightning in a tornadic storm on 8 May 1986. Mon. Weather Rev., 119, 1557-1574

The electrical nature of storms. Oxford University Press, New York, USA

2001 'An overview of the STEPS field program'. Pp. 27-28 in Preprints of the International workshop on physics of lightning. Nagoya, Japan 
Orville, R. E.

1994

Orville, R. E., Zipser, E. J.,

Brook, M., Weidman, C.

Aulich, G., Krider, E. P.,

Christian, H., Goodman, S.,

Blakeslee, R. and

Cummins, K.

Pertersen, W. A. and

Rutledge, S. A.

Pierrehumbert, R. T. and Wyman, B.

Pinto Jr, O., Pinto, I. R. C. A., Gomes, M. A. S., Vitorello, I. Padilha, A. L., Diniz, J. H., Carvalho, A. M. and Cazetta Filho, A.

Rust, W. D., MacGorman, D. R. and Arnold, R. T.

Rust, W. D., Taylor, W. L., MacGorman, D. R. and Arnold, R. T.

Rust, W. D., MacGorman, D. R. and Goodman, W. J.

Rutledge, S. A., Lu, C. and MacGorman, D. R.

Saunders, C. P. R., Keith, W. D. and Mitzeva, R. P.

Schulz, W.

Seimon, A

Seity, Y., Soula, S. and Sauvageot, $\mathrm{H}$.

Sheridan, S. C., Griffits, J. H. and Orville, R. E.

Smith, S. B., LaDue, J. G. and MacGorman, D. R.

Stolzenburg, M.

Tabary, P.

Tabary, P. and Scialom, G.

Takahashi, T.

Théry, C.

Vivekanandan, J., Zrnic, D. S., Ellis, S. M., Oye, R., Rhyzhkov, A. V. and Straka, J.

Williams, E. R., Weber, M. E. and Orville, R. E.

Williams, E. R., Zhang, R. and Rydock, J.

Zajac, B. A. and Rutledge, S. A.

1997

2001

1985

1999

1981a
Positive cloud-to-ground lightning flashes in severe storms. Geophys. Res. Lett., 8, 791-794

1981b Research on electrical properties of severe thunderstorms in the Great Plains. Bull. Am. Meteorol. Soc., 62, 1286-1293

1985 'Unusual positive cloud-to-ground lightning in Oklahoma storms on 13 May 1983'. Pp. 372-375 in Preprints of the 14th conference on severe local storms. American Meteorological Society, Boston, USA

1990 Positive cloud-to-ground lightning in mesoscale convective systems. J. Atmos. Sci., 47, 2085-2100

1991 The effect of liquid water on thunderstorm charging. J. Geophys. Res., 96, 11007-11017

1997 'Performance evaluation of lightning location systems'. PhD Thesis, Technical University of Vienna

1993 Anomalous cloud-to-ground lightning in a F5-tornado-producing supercell thunderstorm on 28 August 1990. Bull. Am. Meteorol. Soc., 74, 189-203

2001 Lightning and precipitation relationship in coastal thunderstorms. J. Geophys. Res., 106, 22801-22816

1997 Warm season cloud-to-ground lightning-precipitation relationships in the south-central United States. Weather Forecasting, 12, 449-458

2000 The relationship between cloud-to-ground lightning polarity and surface equivalent potential temperature during three tornadic outbreaks. Mon. Weather Rev., 128, 3320-3328

1994 Observations of high ground flash densities of positive lightning in summertime thunderstorms. Mon. Weather Rev., 122, $1740-1750$

2002 'Observations radar de systèmes précipitants orographiques pendant l'expérience MAP'. Thesis, Université Paul Sabatier, Toulouse

2001 MANDOP analysis over complex terrain in the context of the MAP experiment. J. Atmos. Oceanic Technol., 18, 12931314

1978 Riming electrification as a charge generation in thunderstorms. J. Atmos. Sci., 35, 1536-1548

2001 Evaluation of LPATS data using VHF interferometric observations of lightning flashes during the Eulinox experiment. Atmos. Res., 56, 397-409

1999 Cloud Microphysics retrieval using S-Band dual-polarization radar measurements. Bull. Am. Meteorol. Soc., 80, 381-388

1989 The relationship between lightning type and convective state of thunderclouds. J. Geophys. Res., 94, 13213-13220

1991 Mixed phase microphysics and cloud electrification. J. Atmos. Sci., 48, 2195-2203

2001 Cloud-to-ground lightning activity in the contiguous United States from 1995 to 1999. Mon. Weather Rev., 129, 9991019 